Удк 674.817-41

\title{
ИСПОЛЬЗОВАНИЕ КОРЫ ПРИ ПОЛУЧЕНИИ ДРЕВЕСНО-ВОЛОКНИСТЫХ ПЛИТ
}

\author{
(ㄱ Л.И. Лазарева*, Н.Г. Чистова, С.О. Медведев
}

\author{
Сибирский государственный технологический университет, Лесосибирский \\ фрилиал, ул. Победы, 29, Лесосибирск, 662543 (Россия), \\ e-mail: lazarewa.lyuba @yandex.ru
}

\begin{abstract}
Представлены экспериментальные исследования по разработке способа использования измельченной коры в производстве древесно-волокнистых плит. Результаты исследований направлены на решение целого ряда народнохозяйственных проблем, в то числе ресурсосберегающих и экологических.

Ключевые слова: водопоглощение, древесно-волокнистая плита, кора, набухание, показатель фракционного состава, плотность, предел прочности при статическом изгибе, степень помола, танины.
\end{abstract}

\section{Введение}

Огромное количество коры образуется на предприятиях лесного комплекса в процессе переработки древесины и не находит дальнейшего использования в технологических процессах. В целом же по стране накапливается до 10 млн тонн коры, часть которой используется для производства топливных брикетов или высушивается и сжигается [1], а оставшаяся вывозится на полигоны для захоронения. Кора даже не входит в структуру баланса использования пиловочного сырья, и объемы ее накопления на предприятиях практически не учитываются.

Несмотря на то, что в настоящее время проводятся многочисленные исследования и существуют разработки отечественных и зарубежных авторов по использованию коры, в том числе и в производстве плитных материалов, кора в промышленных условиях перерабатывается малоэффективно. Отсутствие интереса к коре в качестве сырья главным образом объясняется тем, что при существующих технологиях производства древесных плит использование коры в количестве свыше $15 \%$ от массы абсолютно сухого волокна ухудшает прочностные показатели готовых плит $[2,3]$. Как известно, в химический состав коры входят природные полифенолы - танины (танниды), которые можно использовать при изготовлении связующих. Данный факт позволяет высказать предположение о возможности применения специальным образом подготовленной коры в производстве древесных плит с сохранением физико-механических характеристик готового изделия. В данном случае кора может исполнять роль не только наполнителя, но

Лазарева Любовь Ивановна - старший преподаватель кафедры технологии производства в лесном комплексе, тел.: (39145) 6-28-03, e-mail: lazarewa.lyuba@ yandex.ru Чистова Наталья Геральдовна - профессор кафедры лесоинженерного дела, доктор технических наук, тел.: (39145) 6-28-03, e-mail: chistova_n_g@mail.ru Медведев Сергей Олегович - ассистент кафедры экономики и управления на предприятии, тел.: (39145) 6-01-29, e-mail: medvedev_serega@mail.ru и упрочняющей добавки. Таким образом, исследования по разработке эффективных и недорогих способов использования коры являются, безусловно, актуальными, поскольку кора это доступное и ценное с точки зрения богатого химического состава сырье. Решение проблемы утилизации коры направлено на улучшение экологической обстановки на деревообрабатывающих предприятиях.

\footnotetext{
* Автор, с которым следует вести переписку.
} 
В Лесосибирском филиале Сибирского государственного технологического университета проводятся исследования по разработке способа использования коры в производстве древесно-волокнистых плит. Результаты ранее проведенных экспериментов показали, что различные виды коры (березовая, еловопихтовая, сосновая) влияют на физико-механические характеристики плит по-разному. Наилучшие прочностные характеристики достигаются при использовании в качестве добавки измельченной сосновой коры. Учитывая объемы переработки сосновой древесины на предприятиях Ангаро-Енисейского региона (до $70 \%$ ), для дальнейших исследований в качестве добавки в работе рассматривали сосновую кору.

\section{Экспериментальная часть}

Кора перед введением в древесно-волокнистую массу измельчалась и фракционировалась. Для измельчения использовали мельницу, работающую по сухому способу размола. В качестве входных факторов эксперимента приняли содержание коры по отношению к массе абсолютно сухого волокна и размер частиц коры. Содержание коры варьировалось в интервале от 2 до 18\%. Размеры частиц коры соответствовали размерам ячеек сит, на которых оставалась данная фракция коры при фракционировании на установке ФВГ-2. Экспериментально было установлено, что при размоле неокоренного сырья по существующей технологии производства ДВП средний размер коры в готовых плитах равен 0,6 мм. Поэтому для дальнейших исследований установили верхний уровень интервала варьирования фактора размер частиц коры 0,6 мм, нижний $-0,4$ мм, середина интервала $-0,5$ мм. Измельченная кора замачивалась в воде при температуре $60{ }^{\circ} \mathrm{C}$ и выдерживалась в течение 2 ч.

В качестве сырья использовали технологическую щепу из древесины лиственных пород с породным составом: $50 \%$ березы, $25 \%$ осины и $25 \%$ тополя. В лабораторных условиях согласно принятому технологическому режиму производства древесно-волокнистых плит получали древесно-волокнистую массу путем размола в две ступени (дефибратор, рафинатор). Степень помола массы на первой ступени - 11-12 ДС, на второй - 22-24 ДС, или 11,5 ШР, фракционный показатель качества волокна - 33 г. В полученную древесноволокнистую массу добавляли фенолоформальдегидную смолу, парафиновую эмульсию, водный раствор серной кислоты и предварительно замоченную кору с установленными и принятыми размерами и заданным количеством массы. Отлив ковра и прессование плит производили на лабораторном оборудовании согласно режимам технологического процесса полученя ДВП мокрым способом. Эксперимент реализовывался при всех прочих равных условиях с добавлением сосновой коры. Каждый опыт дублировался пять раз.

В качестве выходных параметров эксперимента, определяющих качество древесно-волокнистых плит, согласно ГОСТу 4598-86 «Плиты древесноволокнистые мокрого способа производства», приняты предел прочности при статическом изгибе, плотность, набухание по толщине и водопоглощение за 24 ч.

\section{Обсуждение результатов}

Внешний вид полученных в результате эксперимента плит представлен на рисунке.

Из рисунка видно, что внешний вид древесно-волокнистых плит зависит не только от количества коры, но и от размеров частиц коры в плите. Плиты с содержанием коры $18 \%$ к а.с.в и размерами коры 0,6 мм отличаются неоднородностью окраски и большой шероховатостью.

Результаты экспериментальных исследований, полученных при проведении эксперимента, приведены в таблице.

Анализ полученных результатов позволяет говорить о том, что на прочность и гигроскопичность готовой продукции оказывает существенное влияние не только количество коры в древесно-волокнистой плите, но и ее размеры. Однако существенного влияния размеров частиц коры на плотность плиты не установлено, но увеличение процентного содержания коры в плите значительно снижает плотность. Так, при увеличении содержания коры в плите на $16 \%$ плотность снижается в среднем на $150 \mathrm{\kappa r} / \mathrm{m}^{3}$.

Древесно-волокнистые плиты с меньшими размерами частиц коры обладают наилучшими показателями по величине предела прочности при статическом изгибе, а также по набуханию и водопоглощению за 24 ч. Причем наблюдается тенденция улучшения показателей по прочности, набуханию и водопоглощению при увеличении содержания коры от 2 до 10\%, дальнейшее повышение содержания коры до $18 \%$ ухудшает физико-механические характеристики. Так, предел прочности при статическом изгибе при содержании коры $10 \%$ существенно превышает предел прочности образцов с содержанием коры 2 и $18 \%$, к тому же этот образец имеет наименьшее набухание и соответствует требованиям ГОСТа 4598-86. 

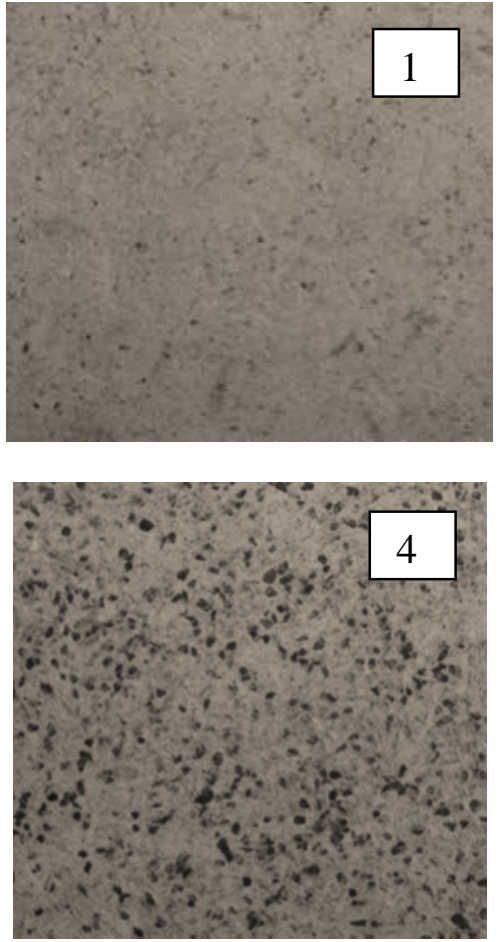
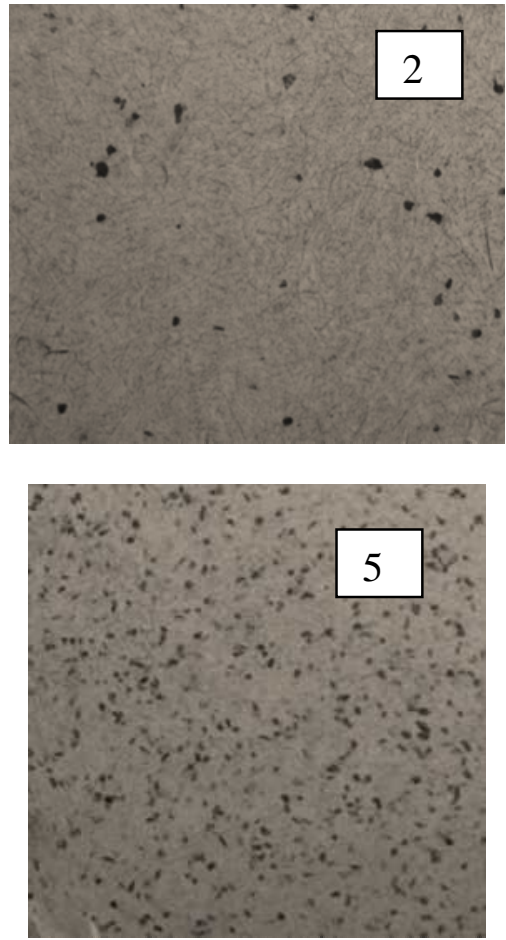

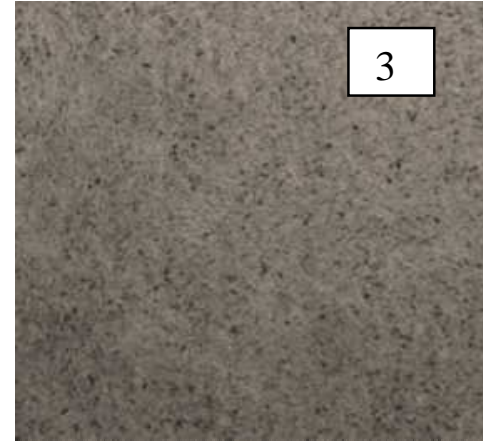

Внешний вид плит с добавлением коры сосновой. 1 - содержание коры $2 \%$, размер коры 0,4 мм; 2 - содержание коры 2\%, размер коры 0,6 мм; 3 - содержание коры $18 \%$, размер коры 0,4 мм; 4 - содержание коры 18\%, размер коры 0,6 мм; 5 - содержание коры $10 \%$, размер коры 0,5 мм

Результаты эксперимента

\begin{tabular}{|c|c|c|c|c|c|c|}
\hline \multirow{2}{*}{$\begin{array}{c}\text { № } \\
\text { опыта }\end{array}$} & \multicolumn{2}{|c|}{ Входные факторы } & \multicolumn{4}{|c|}{ Выходные факторы } \\
\hline & $\begin{array}{c}\text { Размер } \\
\text { коры, мм }\end{array}$ & $\begin{array}{c}\text { Содержание } \\
\text { коры, \% }\end{array}$ & Плотность, кг $/ \mathrm{M}^{3}$ & Прочность, МПа & Набухание, \% & $\begin{array}{c}\text { Водопоглощение, } \\
\%\end{array}$ \\
\hline 1 & 0,4 & 2 & 1026,63 & 39,6 & 25,97 & 31,48 \\
\hline 2 & 0,6 & 2 & 1029,17 & 37,6 & 27,7 & 35,12 \\
\hline 3 & 0,4 & 18 & 880,09 & 29,4 & 20,5 & 23,97 \\
\hline 4 & 0,6 & 18 & 874,36 & 21,3 & 22,5 & 28,89 \\
\hline 5 & 0,5 & 10 & 937,88 & 44,6 & 15,84 & 25,3 \\
\hline \multicolumn{3}{|c|}{ ДВП марки Т по ГОСТ4598-86 } & $800-1000$ & не менее 33 & не более 23 & не нормируется \\
\hline
\end{tabular}

\section{Выводы}

При содержании коры $18 \%$ существенно изменяется цвет готовой продукции, поэтому применение способа глубокого крашения будет затруднено. Отделка таких плит пленками нежелательна из-за повышения шероховатости поверхности, в большей степени это касается плит с размерами коры 0,6 мм.

Фракционный состав коры оказывает также влияние на прочность, набухание и водопоглощение древесно-волокнистой плиты, с уменьшением размеров коры эти показатели улучшаются. Наилучшие показатели по прочности, набуханию и водопоглощению достигаются при содержании коры в количестве $10 \%$ от массы абсолютно сухого волокна.

Исследования по разработке способа использования измельченной до определенного гранулометрического состава коры в производстве древесно-волокнистых плит являются перспективными, так как направлены на решение целого ряда технологических, экологических и экономических задач. Частичная замена исходного сырья (древесного волокна) измельченной корой повышает процент комплексного использования сырья на предприятии и снижает себестоимости древесно-волокнистых плит. Использование коры в качестве наполнителя и упрочняющей добавки в производстве ДВП уменьшает токсичность готовой продукции и улучшает экологическое состояние промышленных площадок деревообрабатывающих предприятий, снижая затраты на вывозку и утилизацию коры. 


\section{Список литературы}

1. Никишов В.Д. Комплексное использование древесины. М., 1985. 264 с.

2. Житков А.В. Утилизация древесной коры. М., 1985. 136 с.

3. Зыков Ф.И. Основные направления использования древесной коры и исследованияе механизмов для ее измельчения // ЦНИИМОД. Научные труды. Лесопильное производство. Архангельск, 1966. Вып. 20. С. 111-144.

Поступило в редакичию 16 февраля 2012 2.

Lazareva L.I. , Chistova N.G., Medvedev S.O. THE USE OF BARK IN OBTAINING WOOD-FIBER PLATES

Siberian State Technological University, Lesosibirsk branch, Pobeda Street, 29, Lesosibirsk, 662543 (Russia), e-mail: lazarewa.lyuba@yandex.ru

The article presents experimental studies on the development of ways how to use the powdered bark in manufacture of wood-fiber plates. The results of studies are aimed to solve different people s and economic problems including environmental problems.

Keywords: Water absorption, wood-fiber plate, bark, swelling, parameter of the fractional structure, density, the ultimate strength in static bending, degree of grinding, tannins.

\section{References}

1. Nikishov V.D. Kompleksnoe ispol'zovanie drevesiny. [Integrated use of wood]. Moscow, 1985, 264 p. (in Russ.).

2. Zhitkov A.V. Utilizatsiia drevesnoi kory. [Disposal of tree bark]. Moscow, 1985, 136 p. (in Russ.).

3. Zykov F.I. TsNIIMOD. Nauchnye trudy. Lesopil'noe proizvodstvo. Arkhangelsk, 1966, no. 20, pp. 111-144. (in Russ.).

Received February 16, 2012

\footnotetext{
"Corresponding author.
} 